\title{
Ghanaian Migration to the Netherlands: Status Paradox?
}

\author{
Amisah Zenabu Bakuri \\ University of Amsterdam, Amsterdam, the Netherlands
}

\begin{abstract}
Migration continues to serve as platform for financial and social empowerment in many countries including Ghana. There are many constraints associated with the life of migrants; however, the quest to be socially acknowledged enables them to adopt certain survival strategies. Using qualitative methodology, this paper examines Ghanaians migration to the Netherlands using the concept of "burger". This research work highlights that some Ghanaian migrants travel with the goal of earning money to meet their personal and family needs, and so engage in any available job to build and maintain their new burger status. As burgers, they have to obtain enough money to maintain their elevated social status but need to ensure that relatives and friends in Ghana do not know how this money is obtained. To maintain the new "privilege” social status often ascribed to Ghanaians living abroad, migrants are compelled to juggle their work, income, and lifestyle in the Netherlands and (mis)-representation of themselves in Ghana.
\end{abstract}

Keywords: migrants, burger, returnees, Ghana, the Netherlands, social status

\section{Introduction}

In this study, I focus on migrants from Ghana living in the Netherlands often called burgers by most Ghanaians. ${ }^{1}$ In simple terms, the notion of burger comes with its certain social prestige as well as responsibilities. Following Nieswand that burgers experience a status inconsistency, which he called the status paradox of migration, I explore the notion of burger in the context of Ghanaian migrants in the Netherlands (Nieswand, 2014). Nieswand highlights that burgers gain status in the sending regions by simultaneously losing it in the receiving regions. Therefore, migrants often switch social positions in the host country and that of their country of origin. In this paper using ethnographic methods I explore further the notion of burger among these migrants.

In the early 1980s, Ghanaian migrants living in Nigeria were expelled in great numbers and many of them began to seek political asylum and economic opportunities elsewhere across the world. Ghana's economy deteriorated in the 1980s and the political crisis that led to a coup d'état in 1981 further worsened the situation of the ailing economy. Europe appeared to be a place of stability and prosperity so many Ghanaians explored that opportunity. Migrants from Ghana did not only focus on settling in Great Britain (the former colonizer) but also in other European countries such as Germany, Italy, and the Netherlands. The data from this study collaborates with previous literature and shows that historically, Ghanaian migration to Europe often centred on

Amisah Zenabu Bakuri, Ph.D. candidate, Research Master, Modern History and International Relations, University of Amsterdam, Amsterdam, the Netherlands.

${ }^{1}$ The etymology of burger is often traced to the name of the German city Hamburg, a popular destination among Ghanaians during the late 1970s and 1980s. The word burger refers to a migrant in general and not necessarily one who has lived in Hamburg. 
the United Kingdom (UK) and Germany rather than the Netherlands. For most of these migrants, the UK and Germany provided better opportunities to continue with their education (Buchan \& Dovlo, 2004; Awuah, 2005). Most Ghanaians who went for further studies had funding and the skilled workers were in high demand outside Ghana and were also well paid. In this paper, most of the interviewees unlike those who settled in the UK or Germany noted that they came to the Netherlands because of economic motivations.

Getting to the end of the 1970s, the labour market in the Netherlands was showing the need for extra labour force. Previously in the mid 1960s, the Dutch organised and recruited labour force specifically from Morocco and Turkey. However, there were no organised recruitments of labour force in the 1970s and so many people from different parts of the world took advantage of the very attractive Dutch labour market. For many Ghanaians, this period coincided with economic crises in Ghana and many moved to the Netherlands. In the Netherlands, many of these migrants were more inclined towards either entrepreneurship or looking for opportunities to make money other than education.

Most of these migrants from Ghana lived under precarious conditions for some time, but saved a considerable amount of their money with the intention that when converted to the Ghanaian Cedis (local currency) was enough to raise ones living standards in Ghana. Because of the high conversion rate of their savings, individuals proudly displayed wealth and profligate lifestyles when they visited Ghana (Kabki, Mazzucato, \& Appiah, 2004). Others also found means to send money and material items as a token of their love and care for their families. However, these actions of the migrants sent signals to other individuals living in Ghana that migration was a gateway of raising their standard of living and possibly change the fortunes of their family and dependants.

In this paper therefore the term - the burger - as widely used by Ghanaians in reference to an overseas migrant, will be explored to further understand migration from Ghana to the Netherlands. The relativity in the social positions of Ghanaian migrants in the Netherlands and in Ghana will be explored. Using the notion of transnational status paradox, the study explores migration from Ghana to the Netherlands. This is done to differentiate situations that may prevail in other countries, but also the similarities that may be present for migrants. In addition, I focus on the representations and negotiations of the burgers' status both in the Netherlands and in Ghana. It is important to understand that Ghanaians in the Netherlands do not form a homogeneous group, but differ greatly in regard to their migration histories, religious belonging, socioeconomic and educational background, and legal status.

\section{Migration From Ghana}

Historically and increasingly so today, migration represents a major development opportunity for various migrants (World Commission, 2004). Migration sometimes functions almost like a "rite of passage" to social recognition in some societies, and so "pushes" people to engage in it. West Africans have a phenomenal predisposition for mobility over a long period of time (Arthur, 1991). This is notably true in the case of Ghanaians, where migration represents a long tradition. Ghana, formerly the Gold Coast, has historically experienced diverse forms of migration flows within its geographical setting, and other countries in Africa. ${ }^{2}$ Some Ghanaians migrated to West African countries such as Nigeria and Côte d'Ivoire (Brydon, 1985). Although many Ghanaian migrants settled in other countries in the Economic Community of West African

2 Prior to 1957, when Ghana gained independence from the British it was called the Gold Coast. 
States (ECOWAS), one of their major complaints was that conditions are not better than in Ghana. Most of these migrants wanted economic rewards rather than a cultural experience. This is probably one of the reasons why migration focus shifted from within the West African Region to other parts of the world particularly European countries including the Netherlands. In this study, some interviewees noted that migration to other West African countries served as transit zones to get to European countries.

In Ghana, migration is seen as an achievement that enhances the migrant’s social status-“the burger status”. In addition to the elevated social status of migrants, it is believed that migration offers a quicker and a sustainable route to economic freedom. In this sense, it is the socioeconomic pressures that serve as motivation for some Ghanaians to emigrate (UN, General Assembly, 2004). Ghanaians who migrate to Europe often do so voluntarily or are forced by their precarious economic situation to migrate in search of elusive and sometimes insecure as well as low paying jobs (Oppong, 2006).

\section{Ghanaians in the Netherlands}

The first remarkable wave of Ghanaian migration to the Netherlands took place during the 1980s, a period noted as the peak of unprecedented migration out of Ghana (Donkor, 2005; Orozco \& Mohogu, 2007). This period was characterised by drought, famine, bush fires, political instability and the massive expulsion of Ghanaians from Nigeria. This contributed to Ghanaians living within the country and the returnees from Nigeria to migrate and look for new destinations in Europe and the Netherlands was one of such places.

The Netherlands became very attractive to Ghanaian migrants due to the availability of job opportunities and it's very strong policy emphasis on multiculturalism compared to other European countries (Dijk, 2004; Schans, Mazzucato, Schoumaker, \& Flahaux, 2013; Koopmans, Statham, Giugni, \& Passy, 2005). Though Ghanaians are considered to be one of the most significant African migrant groups in the Netherlands, in terms of the share of all migrants, they represent a minority in comparison with other migrant populations from Morocco and Turkey (Mazzucato, 2008).

As of 1st January 2016, Centraal Bureau voor de Statistiek (CBS, 2017) reported that there were 23,168 Ghanaians legally resident in the Netherlands. The number of Ghanaians in the Netherlands remains uncertain despite official figures. It was estimated that over 3,000 Ghanaian migrants lived in the Netherlands unofficially in 1992 (Knipscheer, Broese van Groenou, Leene, Beekman, \& Deeg, 2000). ${ }^{3}$ This CBS data does not include the large number of "undocumented" Ghanaian migrants suspected to be living in the Netherlands. The actual number of Ghanaians resident in the country is likely much higher than suggested by official statistics.

The Ghanaian migrants in the Netherlands organise themselves in associations on the basis of religion, ethnic and occasionally political lines. ${ }^{4}$ According to the Ghana Embassy in the Netherlands, there are over 70 organised groups, with the majority based in Amsterdam and the remaining spread across The Hague, Rotterdam, and Utrecht (Ghana Embassy, Ghanaian Community, 2017). These Ghanaian associations have well developed structures that usually contain the form of networks that provide community living and other services connected to the everyday lives of these migrants in the Netherlands.

\footnotetext{
${ }^{3}$ Due to a plane crash in a suburb of Amsterdam when it was noted that many Ghanaians were either directly or indirectly victims of this disaster, the Ghanaian population in 1992 quickly became a "hot item" in media as well as for academic research.

${ }^{4}$ Examples of such groups include Sikaman Foundation and Ghana Students Association Enschede.
} 


\section{Methodology}

Data for this paper formed part of my postgraduate thesis dissertation titled "The Invisible Ghanaian Sex Worker Active in the Dutch Sex Industry”. The core data for this study was collected using in-depth interviews, focussed group discussions, informal conversations and observation. Generally, however, I had prior informal conversations with all categories of informants in the Netherlands and the UK. Specifically, in-depth interviews were conducted with 36 informants. This comprised of 25 migrants still based in the Netherlands, three migrants who have relocated to the UK from the Netherlands, and three "returnees" (migrants who have relocated to Ghana). In addition, the parents of five of the immigrants in the Netherlands were interviewed in Ghana. Again, I used focus group discussion with six Ghanaian migrants formerly living in the Netherlands but currently living in the UK, as well as informal discussion and conversation with several Ghanaian migrants at their homes and churches and at functions (parties and weddings) organised by various Ghanaian groups in the Netherlands.

Snowball sampling method with its numerous advantages was used to access interlocutors (Poeze, 2010). While some interviewees were met through introductions, this research method also involved spontaneity and in some cases chance encounter. Real names of key informants and interlocutors are not disclosed in the analyses and discussions of interviews, as most of them were not comfortable about revealing their identity. I do this as part of ethical considerations, in addition, the residential status of some respondents (some are undocumented). In cases where I decide to use names I only use pseudonyms to make the analyses.

Respondents were interviewed in English and the widely spoken Ghanaian language, Twi. The choice of language for the respective interviews depended on preference and fluency in the language chosen. ${ }^{5}$ Interviews of Ghana-based respondents were conducted by phone and Skype to save time and cost. All interviews were recorded.

It must, however, be noted that sometimes, the average Ghanaian does not know the differences between the European countries and lump all together as abroad-“aburokyire”. Others do mix up the countries and cannot distinguish one European country from the other. Data from this study and my experiences attest to this fact. Before I set off to the Netherlands for my studies in the summer of 2012, a family member noted how I could stay with my aunt who lives in London. During the fieldwork for this study, some of the interviewees in Ghana sometimes lumped up the stories they hear from different parts of Europe, as if it happened in one location. I tried to avoid the lumping up by reiterating that my focus is on Ghanaians in the Netherlands.

\section{Profile of Respondents}

Data collection for this paper was started from September 2013 to June 2014. During the data collection period the followings are the profiles of my respondents based on the data collection procedure earlier described. In-depth interviews of 36 respondents based in the cities of The Hague, Rotterdam, Amsterdam, Groningen and Zoetermeer (The Netherlands), Accra and Kumasi (Ghana), and London (United Kingdom). Many of the migrants interviewed arrived in the Netherlands approximately 25 years ago with few exceptions (some have been in the Netherlands for up to 35 years and one had arrived three years ago). Some of them were currently working as domestic workers, taxi drivers, sales personnel; others were engaged in professions such as teaching and clergy. Nearly all of them professed to be Christians, married with children, and maintained regular links

\footnotetext{
${ }^{5}$ Throughout my interviews (though with some few exceptions), most of the Ghanaians that spoke in Twi were more open and willing to discuss in-depth about issues.
} 
with (extended) family back home in Ghana. As at the time of the interview, the majority of participants' level of education was secondary and a few with primary level. More females participated in this research than males. Many came to the Netherlands directly from Ghana whereas others came to the Netherlands via Germany or Nigeria. A couple of the respondents interviewed in London (United Kingdom), had lived for many years (often between 5 and 12 years) in the Netherlands and decided to move to London for different reasons.

\section{The Burger}

Once a Ghanaian boards a plane to travel beyond the borders of Ghana, he or she automatically acquires or assumes an identifiable and "enviable" social status, known as a "Burger"-a euphemism for a migrant. The notion "Been-to" and the "Burger" as used by Nieswand (2008) and Krause (2010) in the case of Germany and London respectively are characterised by educational aspirations and entrepreneurship of Ghanaian migrants (Nieswand, 2008; Krause, 2010). The Been-to are those elites who went abroad for education. Most migrants who travelled to aburokyire (literally meaning "land beyond the horizon" or "far away land") in the 1980s did not strive for more education, but for improvement of their economic status. Thus, according to Boris Nieswand, the distinction between Been-to and Burger marks a class difference between migrants (Nieswand, 2008). Nieswand explains that the term, burger, is in reference to the city name of Hamburg in Germany and was a major destination of Ghanaian labour migrants in the 1980s as a result of its relaxed migration rules at the time (Nieswand, 2014). Similar terms exist in other countries, in Ivory Coast it is Bengiste; in Senegal it is modou modou, and Tokunbo in Nigeria of the 1960s to the 1980s (Riccio, 2001; Newell, 2005). These burgers often impressed people in Ghana with the money they earned in low paying jobs abroad.

The burger status is associated with some sort of prestige and respect. A burger is one who has succeeded in the migration journey; ${ }^{6}$ and is therefore perceived as a resourceful person who can support the families and reciprocally receive their respect. The ideal type of burger relies on differentials in wealth and buying power as compared to non-migrants. Indeed, families in Ghana expect economic gains from the migrant, and frown on migrants that incur debts. A lot is expected of the burger in terms of financial aid to the family and to the society in the form of contributions in the church and at funerals (Nieswand, 2008).

The conditions of life of Ghanaian burgers abroad are the subject of many highlife music composed by artists who were themselves burgers before and therefore had first-hand experience of the burger life. Two burger musicians who initiated their careers by reflecting on the condition Ghanaian migrants experience abroad are Charles Kwadwo Fosu and Nana Acheampong ("Lumba Brothers") who were based in Germany in the 1980s. Their hit song with Twi lyrics is titled "Yeeya Aka Akwantuo Mu" (literally meaning we are nearly stranded abroad). Hence, the lyrics of this song were based on their observations and experiences. ${ }^{7}$ This song explained how Ghanaian migrants, mostly left the country to seek better fortunes abroad with the aim of returning to Ghana, but due to financial, emotional, or other unforeseen hardships these host countries became permanent places of residence. The song also represents the deep frustrations that some Ghanaian migrants in Europe face.

The burger status remains with the migrant forever, though different phraseology is used to distinguish categories of burgers, depending on their abilities to fulfil the public's expectations about gift giving, a

\footnotetext{
${ }^{6}$ Succeeded in this sense means that the person is resourceful or has material wealth to support the family through remittances.

7 Song is available online at https://www.youtube.com/watch?v=KCY4UW3dBrs. All translations of lyrics from Twi to English are done by the researcher. The song was produced by Akosua Serwaa.
} 
hallmark of burgership. Sarcastic or derogatory phrases denote the loss of public respect, while others denote deep respect and appreciation. The ideal burgers are those that are held in high esteem by family and friends in Ghana, and are referred to as "burger papapaa” (literally, real burger). A real burger (burger papapaa) returns to Ghana with money and goods, but keeps silent about how he arrived at his earnings. He shows off with fancy clothes and jewellery.

Thus, the sarcastic category status burgers have differentials include "burger aye mmere", "burger me neema emmaye”, "Burger m’ahunu wo”, "burger apio” just to mention a few. Thus, on the sarcastic side, "burger aye mmere" (literally, burger is financially weak) is a derogatory term applied to burgers who for various reasons have lost prestige and respect as indicated in the public eye in Ghana. Accordingly, the power of the burger is in relation to his purchasing power or income level. Burgers without adequate money become "weak" and forfeit the symbolic rewards of migration as well as loose the prestige attached to the burger status. Another sarcastic expression, "Burger m’ahunu wo" (Burger, I have seen you) is in reference to the "burger" who has arrived in Ghana but for whatever reason has not visited or brought gifts to friends and families. These types of "burgers" loose prestige because they lack the financial resources and are unable to "dash out" money and gift items. This makes them avoid visiting friends and family. However, the burger resorts to this avoidance tactics as his or her best option to save "face" from public ridicule and perception of being a failure or poor. In addition to the sarcastic category, it is a burger who repeatedly gives excuses that his/her cargo is still in transit (by air or sea) to Ghana or is being held up at Customs clearance unit. "Burger me neema emmaaye” literary, "burger the things or goods that I shipped have not yet arrived or are yet to arrive". The description entails that the migrant returned without gifts for family and friends.

In addition, the song by the Lumba brothers powerfully illustrates how migrants find it difficult to ignore the expectations from "home" as well as the shame and disgrace they face on their return home without the financial power or "muscle" often associated with burgers. Hence, some even decide not to return to their homes because of the associated embarrassment and humiliation. The shame of not meeting the expectations of their family and friends refers to the normative structure of the dominant discourse on migration that defines success as the normality and a failure as a personal insufficiency (Nieswand, 2014). So without succeeding, the migrant "loses face."

The phenomenon of losing face, the difficulties of staying overseas, and the fear of returning home with nothing also feature on several tracks of Amakye Dede’s hit album "Iron Boy” (Mega CD 004). The album, which came out in 1997, was recorded in Germany. Amakye Dede, a Ghanaian music artiste, who lived in Nigeria and Germany, waxed a song that also depicts the real life situations of burgers. However, he stressed that "koru dooso a, yenntena faako nngye animguase", which literally translates as "the existence of many countries or nations or cities suggest that we do not stay in one while losing face”. The lyric alludes that it is better to be on the move to save one's face as a migrant until one "makes it" finally.

Sarkodie $^{8}$ (featuring J. Town) in his song "Borga"12 (another rendition of the term "burger") with the following opening lines “Borga- ena eyee den?” (“You are burger, so what?”), is a lyrical exposé of the unbearable life that Ghanaian migrants face abroad. The musician questions why some individuals would sell their personal possessions to finance a journey that holds no promise of rosy life, but rather condemns one to doing odd and menial jobs abroad to make ends meet. Noting that "Modwene se eda fom, gyae na nipa rebre,

${ }^{8}$ A Ghanaian hip hop and hip life artist. 
Obi te Canada, nea obedi koraa, osre...” (“you think it’s easy abroad, people are suffering; someone lives in Canada but has to beg for sustenance”), Sarkodie critiques burgers for not telling the truth about their precarious existence abroad to their friends and relatives in Ghana.

The status paradoxes of migration are risky. Migration is expected to raise one's status, but it is not often the case. On one hand, the savings of the migrant are not enough to enact the status gained by travelling abroad and maintaining it in Ghana after a permanent return or sometimes during temporary visits. On the other hand, it is not feasible to cut connections with one's family in Ghana in terms of achievement and recognition. Also, it will be very difficult for the migrant to deal with the emotional effects of such action, even though the geographical distance helps the migrant to manage the status by controlling information.

The geographical distance between the place of origin (or where friends and relatives are based/located) involved matters of information and stigma management. Akyeampong emphasizes the linkage between the distance in geography and the management of information when he noted that Ghanaians prefer to migrate to far away countries or destinations whereby their efforts and activities are not supervised or under strict scrutiny by kin (Akyeampong, 2000).

Taking advantage of this space and relative anonymity in a foreign land, migrants are quick to take up any job available. Often, relatives of the migrants seem not to know what the burgers do abroad in terms of their occupation or jobs (Nieswand, 2014). Notably, most migrants from Ghana do not communicate their job description to the family and the family see no need to ask. The paradox is that some families sometimes have an inkling of the low paying or menial jobs that their migrant relatives from Ghana are involved in, but they remain silent about it to save face. This silence signifies not absence of communication, but rather a form of communication, in the process of collaborative form of stigma management. This can even be seen on the obituaries of migrant family members when names of relatives are mentioned either on radio or published in written funeral program of the departed. Is this as a result of the observable ignorance of relatives about the status of migrant activities in the receiving areas or it is just the principle of tact? ${ }^{9}$ Hence, some people are often left to speculate the work the migrants do. In the case of women, the speculations are that they are sometimes involved in sex work, though it is much more likely that they may not be involved in sex work. For men, it is assumed that they are doing very meaning jobs but in cases where they seem to overly rich it is assumed that they deal in narcotic drugs.

In the contemporary global context, at a macro level, the government of Ghana depends on Western and more recently Chinese financial institutions and donor countries for budget support. On a micro-level the economic survival and prosperity of some families are also dependent on having family members abroad. The menial jobs so much hated and rejected in Ghana, are eagerly embraced by migrants from Ghana abroad. This is because valuable foreign currencies translate into higher sources of income due to the conversion rate and depreciation of the Ghana Cedi (the national currency).

\section{Motives and Methods, Expectations and Disillusionment of Migration}

Migration "usually entails personal sacrifices, such as family separation, yet is generally undertaken for the sake of the family. Thus, ambition and commitment figure prominently among the motives for migration"

\footnotetext{
${ }^{9}$ For example, the name of the Burger is mentioned or written together with the country or city of residence (like Mr. George Biney, USA, or Comfort Biney, Amsterdam) while those in Ghana are mentioned or written with their occupation following their name (like Comfort Biney, Teacher, Kumasi).
} 
(Gravil, 1985, p. 523). These personal sacrifices entail physical separation from a migrants "society", family, friends, and loved ones. For many Ghanaians living in the Netherlands I talked to, their migration was a response to an initiative and enterprise. Some Ghanaians consider Europe to be a paradise where one can become rich quicker and easier. ${ }^{10}$ My research participants noted that there are many employment opportunities in Europe and, therefore perceived to be places where they could prosper socio-economically.

For this reason, Ghanaians from diverse ethnicity, age, class, education, and occupation make several attempts to improve their lives through migration. These people will do anything to go to Europe. A case in point is how some will risk their lives to go through Libya to cross the Mediterranean to European countries such as France, Spain, and Italy (Bredeloup, 2012; Lucht, 2012). The different profiles of migrants I interviewed for this study attest to this (see Appendix 1). These migrants weigh available options, sometimes consult with friends and family (using available social networks), take advantage of opportunities offered, and continue to exercise judgment along the way.

However, the process involved in getting to Europe is neither an easy route nor involves cheap cost. Some travellers had to pay huge sums of money to middlemen often known as "connection men" to ensure their passage to the Netherlands, as well as to secure attractive jobs for them. This fieldwork data shows that most people with the proper documents such as invitation letters, passports, and higher education status do not necessarily pay huge amounts of money to connection men when travelling abroad. Notably, majority of individuals involved in this study who were "desperate" to travel abroad normally were willing to do anything to gain the burger status. ${ }^{11}$

From the interviews conducted, economic considerations dominated the reasons migrants gave for migrating to the Netherlands. The reasons for embarking on this burger status are often framed under political and socioeconomic factors with each influencing the other. Findings by Anarfi and Kwankye also noted that, economic reasons mainly underpinned the migration of some Ghanaians within and outside the country (Anarfi, Kwankye, Tiemoko, \& Ababio, 2003). Scholarly works available reveal that, migrants embark on their journey as a result of poverty, unemployment, political, and economic instability in the country of origin (Agustin, 2007; Poeze, 2010; Akyeampong, 2000). Some of these people are also motivated to migrate in search of greener pastures (Akyeampong, 2000; Dijk, 2002; Donkor, 2005). Hence, earning a considerably higher income is an essential motivation for migration. The objective of migrating is not only to earn more money for survival, but it is also broadly associated with the social construction of the ideal life (Olwig \& Sørensen, 2002).

Most of the interviewees indicated that they aimed to make the Netherlands a temporal residence, but when unable to save enough money to go back to Ghana, the Netherlands became a permanent settlement. ${ }^{12}$ One female informant who has lived in the Netherlands for 35 years (a political activist and consultant) noted that the business of buying and selling of cars in Utrecht during the early 1980s drew many Ghanaians in Europe to come to the Netherlands (Utrecht) to buy cars. These were mostly used "second hand" cars in Europe, shipped to Ghana either for their own use or to their kins or traded (car business) to make money. So, it stands to reason that the car business attracted lots of Ghanaians to the Netherlands and in the process, some decided to settle in the Netherlands.

\footnotetext{
${ }^{10}$ Migrants, non-migrants, and prospective migrants.

11 Desperate in that they want to become burgers at all cost. They probably will do anything just to travel abroad.

12 See Lumba song and also Amakye Dede’s song Iron boy
} 
With time, these Ghanaians in Utrecht moved to bigger cities, especially in the capital city of the Netherlands, Amsterdam. This is because there is the perception that in big cities, migrants are more likely to get job opportunities and there is less likelihood for discrimination. With time, the capital of southern Netherlands, The Hague, became another attraction to Ghanaians and it is thus not surprising that the majority of Ghanaians based in the Netherlands are found in Amsterdam and The Hague (Orozco \& Mohogu, 2007). In addition, some interviewees noted that they moved to the Netherlands when conditions of living in other European countries where not favourably anymore in terms of legal documentation and police persecution, limited opportunities for jobs and housing (Bakuri, 2015). They therefore took advantage of the European Union's free movement of people to relocate within Europe.

However, some interviewees noted with disappointment when they realized that life is not so easy in Europe and regretted for leaving behind their (better) jobs (especially those who had formal jobs in Ghana like nurses, teachers, and police officers) or their businesses. ${ }^{13}$ Situations often differ with time and places, for instance in UK, carers (those who take care of the aged and homes) and nurses were in top demand but it is not the same in the Netherlands, a fact confirmed by most of the migrants interviewed who moved from the Netherlands to the UK. In spite of the huge amounts of money spent to get to Europe, women are often vulnerable as they are faced with the grim reality of sex work on arrival. One 42-year-old female care-giver, who lived in the Netherlands before settling in London, noted that:

When I got to the Netherlands, my connection man told me that his job of getting me over to Europe was done and wished me well in my stay. He, however, directed me to seek asylum and that; it was my only means of survival. I met some Ghanaians through the contacts of my connection man. I was told that the way out was to sleep with men for money. And so, I struggled my way through... ${ }^{14}$

Inferring from the above story, it is clear that on arrival in the Netherlands, the myth of Europe as a paradise disappears quickly upon the confrontation with reality. In situations when individuals pay a lot of money to connection men, the disillusion is high. So, in the Netherlands, some of these migrants realize that to eke out a living outside Ghana is not any easier than or as promising as they had previously thought (Surprising Europe 2011). ${ }^{15}$ Undoubtedly, desperations set in when the dreams of migrants turn into nightmares as they realize they need work permits in order to earn a living in Europe. When some migrants successfully acquire permits, they are mostly limited to odd jobs of a few hours per week or at odd hours. In such cases, some weigh available economic opportunities as against high expectations from family and friends in Ghana and their subsistence in the Netherlands, and then may go into the alternative jobs including sex work. ${ }^{16}$

A 47-year-old interviewee who was formally working with a construction firm based in the Netherlands, but now has established his own construction firm noted his frustration at the effects economic crisis had on his life:

Sometimes what to even eat becomes a problem. Because of the economic crisis, some of us were sacked from our work. You have to beg for money before you can even eat. But you have to keep lying to people home. Go and stand by

\footnotetext{
13 Focus group discussion transcript, London, 20 April 2014. However, none of my interviewees indicated that they left behind their better jobs. The contradiction is that they often compared situations in Ghana and recommend that if someone has a good job in Ghana there is no need to travel to Europe.

14 My own translation from Twi to English, Interview transcript, 42 years, female, 16 April 2014.

15 Interview transcripts 2013, 2014.

${ }^{16}$ Migrants interviewed noted that sex work was formerly lucrative in terms of money, however to most; the same cannot be said today due to taxes.
} 
someone's car or you go and stand by someone's house and take a photo. You send the photo home and you say see my car, see my house. It's a shame. ${ }^{17}$

It can be inferred from these interview transcripts above that, some migrants regret coming to Europe but cannot abandon their migration plans because they most likely had not recouped the huge financial investments they made in the process of migration. Most often people either sold all their properties or borrowed money to enable them meet the costs of travel. Others were only able to embark on their journey by relying on many family members who financially and consequently were indebted to them. The costs associated with the process of travel abroad included payment of fees for acquiring a visa from the embassies of countries they planned to visit and eventually settle in, monies needed to buy airline tickets, and fees for connection men.

When certain realities of life at the new destination dawns upon these migrants, they become unhappy and feel "stranded". Notwithstanding these challenges, most of them shy from returning to Ghana as that could lead to total financial ruin as a result of debts or social rejection through the shaming and the name-calling. This is the dilemma of the "stranded" migrant (as noted in the song of the Lumba Brothers "yeeye aka akwantuom", we are nearly stranded abroad). Faced with this dilemma, the migrant becomes desperate and is ready to take any form of work, at all including doing sex work, cleaning floors in shops and offices, becoming chauffeurs, taxi drivers, sales person, and care takers among others.

One of the limiting factors for these migrants in acquiring "respectable" jobs is their educational background. Not only does their educational background limit opportunities for them in Europe but also when they return to Ghana. From the profile of my respondents, perception of Europe as a place to make money and the pride of joining the burger class shaped their determination to travel to the Netherlands. In addition, the educational background of these migrants greatly demotivated them from going back to Ghana. This is because when they even decide to go to Ghana, there will be a challenge of finding a well-paying job to maintain their social status as returned migrants—burgers. The urge to make money in order to gain a better status back home was very important to most of the interviewees.

From my interviews, the life situation for many migrants who came to the Netherlands in the 1980s and 1990s was difficult and precarious due to their unsettled status as "illegal immigrants" and their low academic backgrounds. Due to their low academic background, most of them became limited to job opportunities such as cleaning, sex work, and care giving, among others to cater for their daily needs as well as to meet social pressure from relatives in Ghana. It was much flexible to work in low paid jobs without the proper legal documents (papers), as one could also borrow the documents of friends and family to work.

Speculations among these migrants indicated that some of the Ghanaian women in the Netherlands worked as sex workers to help them enhance their social status (TAMPEP Report, 2009). ${ }^{18}$ Findings from this study support the view-point of some researchers that the main reasons for engaging in sex work are socioeconomic. Most of the migrants I spoke with noted that individuals initially were driven by the socioeconomic imperative of assisting family members and their subsistence to travel to Europe. Some of my female respondents therefore entered the Dutch sex industry in the early 1980s and 1990s. Resultantly, involvement in sex work

\footnotetext{
17 Interview transcript, male, 47 years old, 6 March 2014.

18 This study mainly talks about the female sex worker. This does not aim to dispute the fact that there could be male and transgender sex workers. However, that was not mentioned by many interviewees. Hence, I have deliberately excluded male and transgender sex workers from this study. I therefore see it fit to mainly focus on female sex workers as they are the dominant group (TAMPEP, 2009).
} 
offered some women alternative pathway for better livelihood and self-enhancement, including to have the latest clothing, to purchase land, houses, cars, and other properties to adequately take care of families, finance family members to join them abroad and to set up businesses. Although this was the assertions of the migrants I interviewed, however, none of the female interviewees indicated ever engaging in sex work. They referenced others as going into sex work temporally.

Many migrants are astutely aware that migration for certain types of work has and will continue to elicit the hypocrisy of families, friends, and societies that vilify them. Hence, migrants are forced to navigate between who they think they are, and all that is ascribed to and expected of them from different people-loved ones, neighbours, and society. To the migrants interviewed for this study, they consciously made efforts to keep everything about their work (especially menial jobs) very private.

Usually the subject of Ghanaian migrants and the types of jobs they do are only gossiped and rumoured around. It is always a person pointing hands at the other or telling stories about other people. This is basically because of social norms, social status, social prestige, cultural values, and religious influences leading to stigmatization and social shame. This, therefore, make these migrants result to living secret lifestyles from close friends and families back home. In this regard, migrants are often less truthful about the actual situation and experiences they are going through in the Netherlands. People do not tell about the jobs they do and loved ones hardly ask. This culture of silence could be as a result of positive interest in group solidarity or by such negative impulses such as social "ostracism". Only a handful of people are bold enough to ask about the kind of jobs migrants do in the Netherlands but the responses given by some of these migrants are those that one should be proud of, that is, socially desired answers.

\section{In Ghana, About Migration and Migrant Lives}

This section looks at the perceptions of returnees and families in Ghana about migrants in the Netherlands on migration in general and migrants in particular, in contrast to how the burgers in the Netherlands relate to the expectations of their home-based kin and friends. The need for the burgers to balance the expectations from Ghana with the reality of their living situations in the Netherlands as well as the necessity to meet the expectations when they visit Ghana produces a kind of paradox of maintaining appearances.

In Ghana, people generally assume that some burgers engage in all kinds of work-professional, menial, "dirty work" (referring to the belief that most women burgers engage in sex work and some men in narcotics trading). There is a joke that went viral on social media (Facebook and Whatsapp) about a Ghanaian lady who travelled abroad and went back to Ghana. Upon arrival at her father's house, she met the father who asked her what work she did abroad. When she said she was a prostitute, her father cursed and disowned her, telling her never to return to his house again. However, before the lady left, she told the father she had a fat "brown envelope" for the whole family and thereupon, the father quickly asked her again: "What did you say you were doing abroad again”? She replied that she was a prostitute, but this time the father surprisingly said: "Come here my daughter and hug me, I have missed you, I did not hear you well earlier. I thought you said you were a persecutor”. This joke illustrates how the power of money can erode the social stigma that Ghanaians generally associate with certain kinds of occupations that burgers engage in. In the first instance, families disapprove of certain types of jobs such as sex work, selling drugs among others but on the other hand, the money generated from such kind of jobs are unquestioned, blindly received, and accepted. 
Migrant families in Ghana I spoke with noted that they have had several opportunities to express fears for their children going abroad (aburokyire). This is often because migrants are away from family control. But for these family folks in Ghana, it is prestigious when one's son or daughter or immediate family has gone abroad. Verbal statement such as "Meba wo aburokyire" (My child is overseas) is a common phrase for some parents of these migrants to pride themselves that their children are abroad. Not only do they use verbal phrases but the use of certain clothes and dress codes feature prominently. There is a cloth in Ghana called "Meba wo aburokyire" often bought by burgers for their parents. ${ }^{19}$ Parents proudly wear this cloth to show off to friends and neighbours. Some of these expressions are displayed to show off to their community that, their children are responsible and do not indulge in "dirty" jobs.

Below are some perceptions of interviewed parents about their migrant children:

My daughter was brought up in a Godly manner. She will never get herself into prostitution. She cherishes and loves the Lord and her dignity. ${ }^{20}$

My children are responsible adults. They always discuss issues with me and the family before going ahead with whatever they want to do. I don't think any of them will ever think of going into sex work, they cannot and will not go into sex work... a nurse, a teacher, and the other is a shop owner. My children are very hard working and making the whole family proud. As for the migrants who go into sex work, they are just bad nuts spoiling the (names of the) good ones. They just want to tarnish the image of most migrants. They are very lazy. They want the easy way out, but there is no easy way out in life. We are all witnesses to how many of those sex workers who returned from Ivory Coast died of AIDS. ${ }^{21}$

I have heard several stories of migrant sex workers in Europe, especially in Italy, Netherlands, and Germany. How can a woman be selling her body for money? It's serious and disturbing indeed. In all these, I can confidently say that my daughter will not get herself into prostitution, drugs, or anything immoral. She knows her background, where she is from, a royal $^{22}$ at that and would not sacrifice her dignity on the altar of silver and gold. Not at all! She will sweat to gain what is due $_{\text {her. }}{ }^{23}$

As I noted above some Ghanaians are not aware of the differences in the European countries but as the above transcript shows some parents are clearly aware of these difference and insist on that to avoid lumping up the European countries.

The above transcripts show that in some cases, migrants exhibited remarkable treachery and cunning motives by misinforming relatives about the kind of jobs they are involved in. Some migrants misinform individuals about the jobs they do because they feel these relatives or friends may dissuade them from doing certain (menial) jobs or entering into certain industries .Others do so simply because people will mock or call them names for engaging in certain jobs. To a certain extent, migrants' decisions to engage in these jobs are based on the external pressures and expectations of their families, in particular the needs of their family and necessity to provide resources to their families (, Lauby \& Stark, 1988). Most prominent observation in this study is that these migrants get into certain types of work as a survival strategy in the Netherlands. A large number of the migrants I talked to noted that they do all forms of job to earn some money so they can remit their families in Ghana. In doing so, they feel compelled to shield their work from these loved ones and family as a means to preserve some family pride.

\footnotetext{
19 Notwithstanding, this cloth is easily available on the market and any individual can buy one.

${ }^{20}$ Male, 67 years, Ghana, Skype interview, 15 April 2014.

${ }^{21}$ Female, Ghana, mother with 3 migrant children, 60 years, phone interview transcript, 18 April 2014. My translation from Twi to English.

22 The word royal here means that his daughter has the status of becoming a queen someday.

${ }^{23}$ My translation from Twi to English, male, Ghana, 64 years, phone interview transcript, 22 April 2014.
} 
The financial needs of certain families exert pressure on its members (particularly sons and daughters) to go abroad in order to change the fortunes of the family. In this situation, the family can be seen as an economic unit as well as a social grouping that transcends well-defined labour markets and geographical loci (Lauby \& Stark, 1988). For some of the parents I spoke with, the family members encourage younger members of the family to migrate to Europe or other destinations abroad. Some interviewees $(2013$; 2014) noted how their families invested in their journey by selling off family property. However, others go through all means available to self-sponsor their journey. In the latter case, some of the respondents indicated that they informed or discussed with the immediate family before embarking on their journey. A small cohort of these migrants noted that they only informed family members after they had arrived in the Netherlands.

The fieldwork data shows that migrant families decide to support a member who wants to become a burger if they sense that there is a need for additional income or when financial benefits of the place of destination of the migrant is reasonably high, and the opportunity cost associated with migration is considerably low. Paying or encouraging a relative to travel abroad often depends on the gender of the migrant. The indication to send a particular individual using the criterion of gender is highly influenced by the individual attributes, but also about familial objectives and job opportunities in the host country. ${ }^{24}$

Generally in Ghana, there is close correlation between the prestige that communities accord to the burgers and the influence that the family members of these burgers wield in their local communities. Therefore, to cultivate and maintain lasting respectability, burgers try to provide the financial and material support that their families need to maintain appreciably higher standards of living relative to others in their neighbourhoods that do not have relatives abroad. This is done through regular remittances of money and social allegiance through telephone and other means of digital contact.

In the case of burgers in Netherlands, as my data shows, this active engagement with family is important as it feeds the public perception of how successful the burger has become. To this effect, most parents of these migrants back home create pleasant cover up stories in attempt to preserve the good name of their family and children. For instance, a parent interviewed for this study as noted in the transcripts above explained that her daughter is a nurse but follow-up interview with the daughter showed that she worked as a "carer or care giver” 25 and not as earlier noted by the mother. Another child, who she said was a teacher, was actually into domestic work $^{26}$ and the one she said owns the shop rather works in a factory. I would not want to believe that the woman I interviewed was misleading me. What is being played out here is that sometimes migrants are not able to explain their occupation very well to their parents and people back home. This is because the nature of some of these works is non-existent in most parts of Ghana. Other migrants also feel that it is not important to give the details of their jobs. However, the reality is that some migrant families do not have a clue as to what occupations their children are into abroad.

Also, some families mention jobs that will very well enhance their children's social status. What parents say about their migrant children and the material things people see around the migrant family are all contributions to the social image and the burger status of migrant children. Apart from altruistic motives and filial piety to families in Ghana, some migrants also compensate the family through remittances for helping

\footnotetext{
${ }^{24}$ Including domestic service and sales jobs. Some employers often prefer to hire women because they are considered to be more docile and compliant. There are wage differentials between men and women, where women are believed to be paid less.

25 Taking care of aged and elderly in their homes.

${ }^{26}$ Cleaning private's homes and sometimes babysitting.
} 
them maintain their social status. Hence, there is a set of reasons why migrants may in principle be willing to commit themselves to the transfer of remittances and also maintain good social ties with family.

Many migrants, who remit, do so with the aim of building social networks to enhance their social status and maintain some level of notability or ties back home. However, when people back in Ghana find out about the occupations of these migrants, certain relations become:

1. Affirmed and reinforced,

2. Strained and broken,

3. Initiated and cultivated.

The involvement of migrants in certain jobs could leave to relationships becoming strained and broken. This means losing face, hence some migrants decide to be less candid with the jobs they do.

\section{Conclusion}

The concept of burger is very useful in understanding Ghanaian migrants in the Netherlands. The status attached with being a migrant in Ghanaian society is often higher in spite of the difficulties some migrants face in Europe. In fact, the ability of the burger to surmount these challenges and show care to his family in the form of remittance, building and helping other family members to travel abroad or become economically better earns him high social praises and respect. The concept of burger enhances our understanding of the social and economic motivation and context of migration for the people I spoke with. The use of the burger status can be an empirically grounded effort to conceptualise migration, social status, and integration as well as labour issues of Ghanaian migrants in the Netherlands.

Migration to Europe has been seen as very important to the migrant and migrant families. This is because families who nurtured and invested in their young generation get the opportunity to be taken care of in later stages of their life or assisting families to cater for younger ones in order to reduce the burden of care. In such situations remitting becomes a strong moral imperative of the migrant. Before a migrant can remit, they need enough money for their subsistence hence; they need to work. And yet, we need to remind ourselves that the trigger to migrate could be traced back to serious economic challenges in Ghana. In the case of the migrants interviewed for this study, the economic hardships and political instability in the 1980s were the main push factors to travel to Europe.

After travelling, some Ghanaians adopt the get-money-quick strategy: They go for any available job such as sex work to make money fast, with the aim of returning to Ghana wealthy. However, as shown in some burger songs such as that of Lumba brothers and Amakye Dede, migrants who feel unfulfilled are unable to go back to Ghana due to shame and embarrassment. They, therefore make the Netherlands a permanent stay. Being a burger (migrant) is equated to being on a highway to material success. Migration is therefore a means for the improvement of the migrant's social status. It is also an assurance that a safety net has been cast for the future of the migrant and the family. Indeed, the hope of the average Ghanaian is to travel outside Ghana so as to make strong, steady, and "fast” progress in life.

\section{References}

Awuah, G. (2005). As I journey along: Ghanaian perception of life in the Diaspora. North Carolina: Lulu.com. Arthur, J. (1991). International labor migration patterns in West Africa. African Studies Review, 34(3), 65-87. Akyeampong, E. (2000). Africans in the Diaspora: The Diaspora and Africa. African Affairs, 99(395), 183-215. 
Anarfi, J., Kwankye, S., Tiemoko, R., \& Ababio, O.-M. (2003). Migration from and to Ghana: A background paper. Working Paper C4.

Agustin, L. M. (2007). Sex at the margins: Migration, labour markets and the rescue industry. London: Zed Books.

Brydon, L. (1985). Ghanaian responses to the Nigerian expulsions of 1983. African Affairs, 84(337), 561-585.

Buchan, J., \& Dovlo, D. (2004). International recruitment of health workers to the UK: A report for DFID. doi:10.1136/bmj.330.7485.210

Bredeloup, S. (2012). Sahara transit: Times, spaces, people. Population, Space and Place, 18(4), 457-467.

Bakuri, A. Z. (2015). Ghanaian migrants in the Netherlands: Germany as a transit zone. In A. Akinyoade and J.-B. Gewald (Eds.), African roads to prosperity: People en route to socio-cultural and economic transformation (African dynamics; v. 14) (pp. 232-263). Boston: Brill.

CBS. (13 June 2017). Retrieved from http://opendata.cbs.nl/Dataportaal/\#/CBS/en/dataset/37325eng/table?graphtype=Table\&ts=1497357049136

Dijk, R. (2002). Religion, reciprocity and restructuring family responsibility in the Ghanaian Pentecostal Diaspora. Oxford: Berg.

Dijk, R. (2004). Negotiating marriage: Questions of morality and legitimacy in the Ghanaian Pentecostal Diaspora. Journal of Religion in Africa, 34(4), 438-467.

Donkor, M. (2005). Marching to the tune: Colonization, globalization, immigration, and the Ghanaian Diaspora. Africa Today, 52(1), 27-44.

Ghana Embassy, Ghanaian Community. (2 July, 2017). Retrieved from http://www.ghanaembassy.nl/index.php/ghanaian-community.html

Gravil, R. (1985). The Nigerian aliens expulsion order of 1983. African Affairs, 84(337), 523-537.

Kabki, M., Mazzucato, V., \& Appiah, E. (2004). Wo benane a eye bebree: The economic impact of remittances of Netherlands-based Ghanaian migrants on rural Ashanti. Population and Development Review, 10, 85-97.

Krause, K. (2010). Sickness, migration and social relations: Therapeutic practices and medical subjectivities among Ghanaian migrants in London (Theses, University of Oxford).

Knipscheer, C. P. M., Broese van Groenou, M. I., Leene, G. J. F., Beekman, A. T. F., \& Deeg, D. J. H. (2000). The effects of environmental context and personal resources on depressive symptomatology in older age: A test of the Lawton model. Ageing \& Society, 20(2), 183-202.

Koopmans, R., Statham, P., Giugni, M., \& Passy, F. (2005). Contested citizenship: Immigration and cultural diversity in Europe. Minneapolis: University of Minnesota Press.

Lucht, H. (2012). Darkness before daybreak: African migrants living on the margins in Southern Italy today. Berkeley: University of California Press.

Lauby, J., \& Stark, O. (1988). Individual migration as a family strategy: Young women in the Philippines. Population Studies, 42-43, 473-486.

Mazzucato, V. (2008). The double engagement: Transnationalism and integration—Ghanaian migrants' lives. Journal of Ethnic and Migration Studies, 34(2), 199-216.

Nieswand, B. (2008). Ghanaian migrants in Germany and the status paradox. A multisited ethnography of transnational pathways of migrant inclusion (Ph.D. thesis, Martin-Luther-University of Halle).

Nieswand, B. (2014). The burgers' paradox: Migration and the transnationalization of social inequality in southern Ghana. Ethnography, 15(4), 403-425.

Newell, S. (2005). Migratory modernity and the cosmology of consumption in Côte d'Ivoire. In L. Trager, Migration and economy: Global and local dynamics (pp. 163-192). Walnut Creek: Altamira Press.

Oppong, C. (2006). Introduction. In C. Oppong, M. Yaa, P. A. Oppong, and I. K. Odotei, Sex and gender in the era of AIDS (pp. 1-40). Accra: Sahara Publishers.

Orozco, M., \& Mohogu, M. (November 2007). Remittances from the Netherlands: A survey. Commissioned by Oxfam-Novib, The Netherlands.

Olwig, K. F., \& Sørensen, N. N. (2002). Mobile livelihoods: Making a living in the world. In Work and migration: Life and livelihoods in a globalizing world (pp. 1-19). London: Routledge.

Poeze, M. (2010). In search of greener pastures? Boat-migrants from Senegal to the Canary Islands. Leiden: African Studies Centre. 
Riccio, B. (2001). “Toubab” and "Vu Cumprà”: Italian perceptions of Senegalese transmigrants and the Senegalese Afro-Muslim critique of Italian society. In R. D. Grillo and J. Pratt, The politics of recognising difference. Multiculturalism Italian-style (pp. 177-196). Aldershot: Ashgate.

Schans, D., Mazzucato, V., Schoumaker, B., \& Flahaux, M.-L. (2013). Changing patterns of Ghanaian migration. Mafe Working Paper, 20, 1-31.

TAMPEP Report. (2009). Sex work, migration, health: A report on the intersections of legislations and policies regarding sex work, migration and health in Europe. Germany.

UN, General Assembly. (2004). Women and international migration, world survey on the role of women in development. New York: United Nations.

World Commission on the Social Dimension of Globalisation. (2004). A fair globalisation-Creating opportunities for all. Geneva: ILO. 


\begin{tabular}{|c|c|c|c|c|c|c|c|c|}
\hline \multirow[b]{3}{*}{ Identity } & \multirow[b]{3}{*}{ Place } & \multirow[b]{3}{*}{ Age } & \multirow[b]{3}{*}{ Gender } & \multicolumn{3}{|c|}{ Appendix 1-interviewees Profile } & \multirow[b]{3}{*}{ language } & \multirow[b]{3}{*}{ educational } \\
\hline & & & & \multicolumn{2}{|c|}{ Migrants in the Netherlands } & \multirow[b]{2}{*}{ Date of Interview } & & \\
\hline & & & & Years in NL & occupation & & & \\
\hline A & Den Haag & 53 & Female & 30 & Cleaner & 20th October, 2013 & Twi & primary \\
\hline B & Den Haag & 48 & Female & 28 & Sales person & 16th October, 2013 & Twi and English & secondary \\
\hline C & Den Haag & 50 & Male & 19 & factory worker & 3rd November, $201:$ & English & secondary \\
\hline D & Den Haag & 58 & Female & 28 & Social Welfare & 12th March 2014 & Twi & primary \\
\hline $\mathrm{E}$ & Den Haag & 47 & Male & 13 & \multicolumn{2}{|c|}{ Construction work 6th March, 2014} & English & Technical \\
\hline $\mathrm{F}$ & Den Haag & 42 & Female & 17 & Domestic worker & 16th jUNE, 2014 & Twi & primary \\
\hline G & Den Haag & 59 & Male & 26 & Chauffeur & 3rd April, 2013 & Twi & secondary \\
\hline $\mathrm{H}$ & Den Haag & 55 & Female & 25 & Cleaner & 10th May, 2014 & Twi & secondary \\
\hline 1 & Den Haag & 52 & Female & 24 & Florist & 14th May, 2014 & English & secondary \\
\hline G & Den Haag & 41 & Male & 9 & Taxi Driver & 4th May, 2014 & English & secondary \\
\hline K & Den Haag & 50 & Female & 28 & Sales person & 20th March, 2014 & Twi & secondary \\
\hline L & Den Haag & 56 & Male & 25 & Pastor & \multicolumn{2}{|c|}{ 9th November, 201، English } & tertiary \\
\hline M & Den Haag & 44 & Female & 22 & Cleaner & 29th March, 2014. & Twi & secondary \\
\hline $\mathrm{N}$ & Amsterdam & 41 & Female & 35 & Consultant & 20th May, 2014 & English & tertiary \\
\hline 0 & Amsterdam & 57 & Male & 23 & Pastor & 22nd March, 2014 & English and Twi & tertiary \\
\hline $\mathrm{p}$ & Amsterdam & 52 & Male & 30 & Cleaner & 12th March, 2014 & English & secondary \\
\hline Q & Amsterdam & 36 & Male & 8 & Pastor & 11th May, 2014 & Twi and Engl ish & tertiary \\
\hline $\mathrm{R}$ & Amsterdam & 25 & Female & 6 & Student & \multicolumn{2}{|c|}{ 19th February, 2014 English } & tertiary \\
\hline S & Amsterdam & 49 & Female & 22 & Hair dresser & 6th April, 2014 & Twi & primary \\
\hline T & Rotterdam & 51 & Female & 32 & Cleaner & \multicolumn{2}{|c|}{ 16th February, 2014 Twi } & primary \\
\hline $\mathrm{U}$ & Rotterdam & 33 & Female & 7 & Sales person & 5th April, 2014 & English & secondary \\
\hline V & Rotterdam & 38 & Male & 3 & factory worker & 28th March, 2014 & TWI & secondary \\
\hline W & Gron ingen & 45 & Female & 17 & domestic worker & 3rd June, 2014 & Twi & secondary \\
\hline$x$ & Zotermeer & 28 & Female & 5 & Cleaner & 27th March, 2014 & Twi & secondary \\
\hline Y & Zotermeer & 50 & Female & 27 & Social Welfare & 3rd November, $201:$ & Twi & primary \\
\hline & & & & \multicolumn{2}{|c|}{ Parents Inte rview } & & & \\
\hline identity & Age & \multicolumn{2}{|c|}{ Gender Kids } & Kids in NL & \multicolumn{2}{|c|}{ date of interview language } & & \\
\hline 1. & 64 & Male & 5 & 1 & 22nd April, 2014. & Twi & & \\
\hline 2. & 60 & Female & 7 & 3 & 18th April, 2014. & Twi & & \\
\hline 3. & 67 & Male & 4 & 1 & 15th April, 2014 & English and Twi & & \\
\hline 4. & 73 & Male & 9 & 2 & 10th May, 2014 & Twi and English & & \\
\hline \multirow[t]{2}{*}{5.} & 66 & Male & 3 & 1 & 3rd May, 2014 & Twi and English & & \\
\hline & & & Returnees & & & & & \\
\hline Identity & Age & Yrs in NI & Gender & Occupation & Language & Date of interview & & \\
\hline R1 & 73 & 31 & Male & Retired busin & Twi & 10th May, 2014 & & \\
\hline $\mathrm{R} 2$ & 55 & 23 & Male & Admistrator & English & 2nd June, 2014 & & \\
\hline \multirow[t]{2}{*}{ R3 } & 32 & 6 & Male & NGO officer & English & 6th June, 2014 & & \\
\hline & & & & Migrants in Lo & ondon & & & \\
\hline Identity & Age & Yrs in NI & Gender & Occupation & Date of interview & language & & \\
\hline L1 & 42 & 7 & Female & Carer & 16th April, 2014 & Twi & & \\
\hline L2 & 38 & 12 & Female & Carer & 17th April, 2014 & Twi & & \\
\hline L3 & 45 & 5 & Female & sales prson & 19th April, 2014 & Twi & & \\
\hline & & & Focus group & discussion 20t & th April, 2014 & & & \\
\hline Identity & Age & Yrs in NI & Gender & Occupation & & & & \\
\hline F1 & 36 & 5 & Female & Carer & & & & \\
\hline $\mathrm{F} 2$ & 40 & 7 & Female & Carer & & & & \\
\hline F3 & 44 & 12 & Female & sales prson & & & & \\
\hline F4 & 48 & 5 & Female & Carer & & & & \\
\hline F5 & 41 & 6 & Female & sales prson & & & & \\
\hline F6 & 39 & 9 & Female & Restaurateur & & & & \\
\hline
\end{tabular}

